\title{
ポリビニルアルコール/ポリアリルアミン塩酸塩/水系の 高弾性・高含水ゲルの構造
}

\author{
信州大学織維学部 奈倉 正宣・新井 泰浩・大 越 豊
STRUCTURE OF HIGHLY ELASTIC AND HIGH WATER-CONTENT HYDROGELS OBTAINED FROM POLY(VINYL ALCOHOL)/POLY(ALLYL AMINE)/ WATER SYSTEM

\author{
Masanobu Nagura, Yasuhiro Arai, and Yutaka Ohkoshi
}

Faculty of Textile Science and Technoplogy, Shinshu University, Ueda, 386 Japan

\begin{abstract}
Highly elastic and high water-content hydrogels were prepared by coagulation of concentrated aqueous solutions of poly(vinyl alcohol)(PVA) and poly(allyl amine)(PAIAm) blends in an autoclave at $2 \mathrm{~atm}$ and at $120^{\circ} \mathrm{C}$, followed by dehydration in methanol and re-swelling in water. The elastic moduli of the hydrogels increased with increasing PAIAm content and were higher than those of the PVA hydrogels obtained by repeated freezing and thawing. This was explained based on the presence of rigid phase due to the formation of polymer complex between PVA and PAIAm. The water enclosed in the network had lower mobility than the free water.
\end{abstract}

(Received May 24, 1991)

\section{1. 粕 言}

近年，ポリビニルアルコール(以下 PVA と略記)濃厚 水溶液の反復凍結解凍や低温結晶化によって高弾性・高 含水のゲルの作成が可能なことが発見された $(1,2) 。$ 玄 は[3]このゲル膜のコンタクトレンズへの利用を試 み，良い成果をあげている。このような PVA ゲルの構 造と宫弹性との関係の検討は, Watase, Nishinari (4), 玄ら〔2]によって行われ，結晶が成長することにより 弾性率が向上するとされた。一方, 我々は, 反復凍結解 凍では結晶内分子間及び非晶分子間に結合水や束縛水と しての水が増し，この水が分子間で水素結合することに よって安定な架橋が形成されるためである可能性を指摘 してきた $(5,6)$ 。

膜の透過機能については多くの研究があるが, PVA 系ゲル膜の透過性の研究に関しては，草野らが[7]，変 性PVAのゲル膜を用い酸素富化膜を作製する試みを行 い、また比嘉らが(8)，PVA 荷電ゲル膜を用いイオン の透過作の検討を行っている。しかしながら、これらの ゲルの構造は詳紐には検討されていない。

反復凍結解凍法により，PVA と解離基を有する水溶
性高分子とをブレンドし新しい機能性高分子ゲルを作成 する試みもなされている。鈴木は $[9]$ ，人工筋肉の開発 を目指しPVAとカチオン性，及びアニオン性の雨方の 高分子からなる非常に薄いブレンドハイドロゲル膜を作 製し， pH 变化による膨潤・収綰性の検討を行ない，収 縮速度，収維力の検討進めている。

以上見てきたようにダル膜の構造に関する検討は全体 的には少ない。そこで我々は，最近ではPVAを含むブ レンドハイドロゲルの構造，特に架橋構造について注目 し検討を進めてきた。反復凍結解凍法によるブレンドゲ ルについては，PVAとアルギン酸とのブレンド系につ いて検討し報告した $[10]$ 。更に，我々は最近, PVAと その他の水溶性高分子を，オートクレーブ中で単にブレ ンドすると液相と凝集相に相分離する事に着目し，その 得られた凝集物をメチルアルコールに浸漬，艄水㘼，再 び水で膨潤して得られる物質は，反復凍結解凍法による PVAハイドロゲルよりもかなり強靱なものができるこ とを見いだし[11]，PVAと中性高分子のポリエチレン グリコール(PEG)，およびPVAとアニオン性高分子の 一つであるポリグルタミン酸ソーダ(PSLG) とから得ら れたブレンドハイドロゲルの搆造を検討し，PVAに 
PSLG P PEG をブレンドすることによりPVA 微結晶の 他に离分子間のコンブレッタスが形成され强鞋となる 事，そしてこれらのゲルは蚻のオーダーで三次元的な 蜂の紧状楧造をとることなどを明らかにした〔12-14〕。

本研究では，上記オートクレープ法による強靶なブレ ンドハイドロダルの，上り一般的な構造を明らかにする 目的でPVAとカチオン性水溶性高分子の一つであるポ リアリルアミン(以下 PAlAm と略記)上をブレンドして 得られるハイドロゲルの構造を检討した。

\section{2. 実検}

ポリビニルアルコール(PVA)は(株)クラレより提供 された重合度 1200 ，ケン化度 $98.5 \%$ ののを使用した。 ポリアリルアミン塭酸塩(PAIAm)は日東紡績(株)藵一 般用 PAIAm $\cdot$ HCl-1OS, 分子量50,000-83,000のもの を使用した。

ブレンドハイドロゲル試料の作製はPVA:PAlAmを 重量比でそれぞれ 5:5，4:6，3:7，2:8，1:9そして水溶 液濃度を $25 \mathrm{wt} \%$ と公るよう調整後。これらを $120^{\circ} \mathrm{C} 2$ 気 生のオートクレーブ中で加熱, 加圧し，相分㒕によって 得られた凝集物をメタノール中で 1 週間脱水し, 再び水 で膨潤したものをブレンド八イドロゲル試料とした。

弾性率の测定は，オリエンテック(株)製 TENSILON UTM-而型張陚歌機を用い，ハイドロゲルを試料長10 $\mathrm{mm}$, 幅 $5 \mathrm{~mm}$ にカッターで成形し，切断するまで $20^{\circ} \mathrm{C}$ の水中で引張速度 $20 \mathrm{~mm} / \mathrm{min}$ で引っ張り, 初期勾配から 弾性率を測定した。尚, 厚さが一定に成形困難なため各 試料じとに断面積補正を行った。

電子顕微鏡による微細構造の観察には，日本電子(株) 慗走查型電子顥微鏡 JSM-25型を用い，ゲルをカッター で厚さ約 $1 \mathrm{~mm}$ に切断し，液体窒素に投入し凍結させ $-10^{\circ} \mathrm{C}$ 以下で真空凍結乾燥を行った涷結乾燥試料液

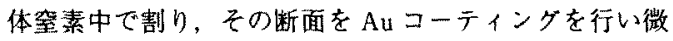
細粠造孝観察した。

熟測定に法，ヒイコ一電子(株)製示差走査熱量計 DSC10を用いた。ダルの溶解挙動は, 容器にステンレ スカプセル，基準試料に蒸留水を使用し，具温速度 1.0 ${ }^{\circ} \mathrm{C} / \mathrm{min}$ ，観測温度範囲 $-20-100^{\circ} \mathrm{C}$ で測定した。凍結乾 橴試料の熱測定は，容器にアルミニウムパン，基準試料 に $\mathrm{Al}_{2} \mathrm{O}_{3}$ 老用い，算温速度 $20^{\circ} \mathrm{C} / \mathrm{min}$, 観測温度範围 0 $300^{\circ} \mathrm{C}$ で測定した。

パルスブロトン核磁気共鳴吸收(PNMR)の测定にはプ ラクシス杜製 PRAXIS-II 製 PNMRを用い，バルス周波 数 $10.72 \mathrm{MHz}$ ，測定温度 $20^{\circ} \mathrm{C}$ でバルス波による ${ }^{1} \mathrm{H}$ 核の 誘導シグナルの遅延時間依存性を測定しケケルのスピン 格子楥和時間 $\left(T_{1}\right)$ 求めた。

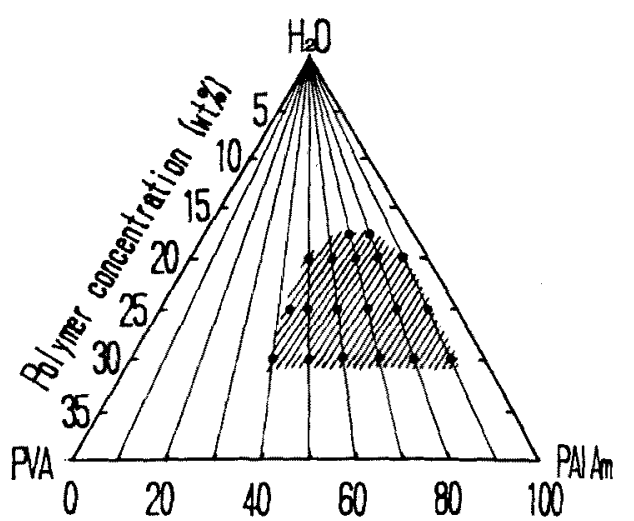

PAlAm content of initial mixture Iwt't

Fig. 1. Compatibility of PVA with PAIAm. A phase separation occurred in the shadowed region in which the experiments were performed under the conditions shown by the closed circles.

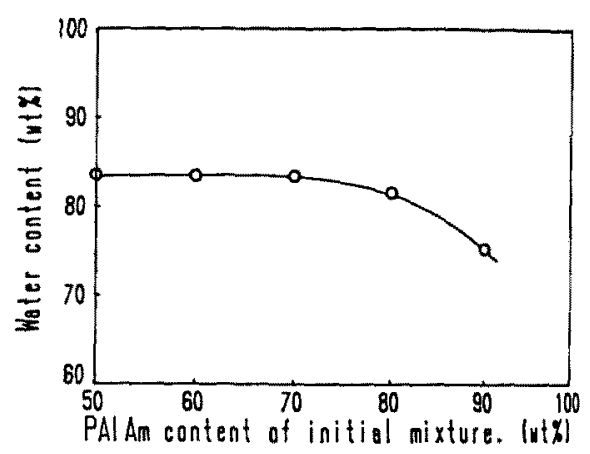

Fig. 2. Dependence of water content of blend gels on PAlAm content of initial mixture.

\section{3. 結果と考察}

\section{1 ブレンドゲル形成来件}

图1は，PVAとPAIAm 及び水との相图を示したもの である。図中に示す黑丸を含む斜線領域ではゲル状の耀 集物が得られ相分離することを表わしている。また，熶 集物が得られる領域の上側と左側ではPVA と PAIAm とは均一溶液を形成し、下側ではPVA 濐度が高〈交》 すぎPVAが溶けきらない状態となる。さらに, PAIAm の初期混合分率が增すと凝集物は巨視的にみて均一で くなり，右側では再じ均一溶液之なる。因に，大気瓜下 では $15 \mathrm{wt} \%$ 以上では溶解しない。そこで，以上の事 は，加圧，加熱に上る効果であると言える。以下の寒转 においては初期高分子浱度 $25 \mathrm{wt} \%$ の場合が最も安定し たダルが形成されるのでこの溶液浱度のものを用いるこ 


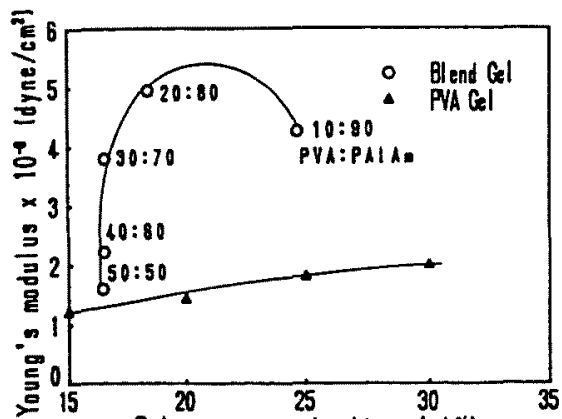

Polymer concentration (utz)

Fig. 3. Dependence of Young's modulus on polymer concentration of PVA gels and blend gels.

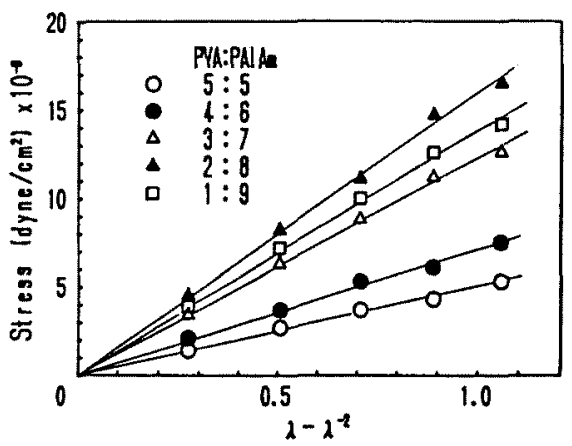

Fig. 4. Dependence of stress on $\left(\lambda-\lambda^{-2}\right)$ of blend gels.

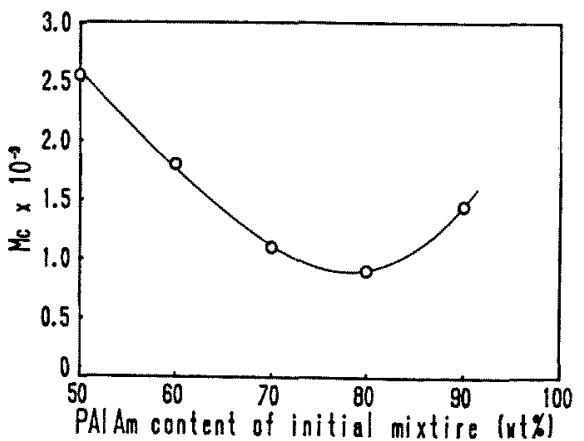

Fig. 5. Dependence of molecular weight per cross-linked unit on PAlAm content of initial mixture.

\section{とにした。}

图 2 は，各ブレンド比試料の水分率を示したものであ る。PAIAm 初期混合分率が增すと僅かに水分率は低下 することがかかる。これはPVAとPAIAm との相互作 用の結果，それぞれのポリマーの周りにあった水分子が 排除され柾水的になることを示唆している。

\section{2 ブレンドゲルの力学的性質}

図 3 はブレンドハイドロゲル試料と反復凍結解凍法に より得たPVAハイドロゲルとの弾性率 [9]のゲル中の 高分子濃度依存性を示したもので，濃度が上がる率が少 ないにも関わらず，弾性率は飛躍的に增大している。 又,ブレンドゲルと PVAハイドロゲルを比較すると最 大約3，3倍も高い弾性率を示している。これらのこと は、ゲルの弾性率增大はゲル濃度の変化によるのではな く，オートクレーブでの PAlAm のブレンドが大きく寄 与しており，その効果はPAlAm の初期混合分率增大に 伴い大きくなることがわかる。これらの傾向は、本研究 と同様に加圧，加熱により得たPVAと中性高分子の PEG 系 [12]，及びPVA とアニオン性高分子の PSLG 系 〔13]のブレンドゲルと同様である。尚，中性高分子の PEG とのブレンドゲルの弾性率はイオン性高分子との 物より，同じ弾性率の物を得るためにはどル濃度を高め る必要があることもわかる。

図 4 はブレンドハイドロゲルのゴム弾性を示したもの である。横軸の值は，延伸率を理想ゴム弾性〔15]にお ける式 $\left(\lambda-\lambda^{-2}\right) に$ 代入した值である。全てのブレンド比 の試料でグラフは，原点を通る直線関係がみられ理想ゴ ム弾性を示すことがわかる。弾性率は一般には上記のグ ラプの傾きの3 倍であることが知られており，その弾性 率から架橋点間分子量を次式により求め[16] PAlAm 初期混合分率依存性を示したのが図 5 である。

$$
\begin{aligned}
& \text { 架橋点間分子量 }=\frac{C R T}{E} \\
& \text { ここで } \quad \mathrm{E}: \text { ヤング率 }\left(\text { dyne } / \mathrm{cm}^{2}\right) \\
& \mathrm{C}: ケ^{*} \text { 濃度 }(\mathrm{wt} \%) \times 10^{-2} \\
& \mathrm{R}: \text { 気体定数 }\left(8.314 \times 10^{7} \mathrm{erg} \mathrm{K}^{-1} \mathrm{~mol}^{-1}\right)
\end{aligned}
$$

PAIAm 初期混合分率 $90 \mathrm{wt} \%$ を除いて PAlAm 分率增大 に伴い架橋点間分子量は減少している。即ち架橋密度增 大を意味している。

\section{3 ブレンドゲルの揞造}

\subsection{1宅子顥微鏡覞察}

図6は，各プレンドハイドロゲル試料の断面をそれぞ れ電子顕微鏡により1000倍で撮影した写真である。全て の PAlAm の試料で，フィルムやテーブを組み合わせた

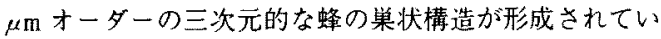
ることがわかる。この構造も又 PVAとPSLG 系のブレ ンドゲルと同様である(13)。この蜂の䉾の大きさは， 特別な系縼的変化は見られない。フィルムやテーブの厚 さも又，PAlAm 分率に依存せずはほ一定のように見え る。そこで, PVAの減少分PAIAmが取り込まれ, 厚さ は変化しないものと考えられる。ゴム弾性から架橋菁造 の変化が予想されたが，電子影微鏡のオーダーで観察さ 


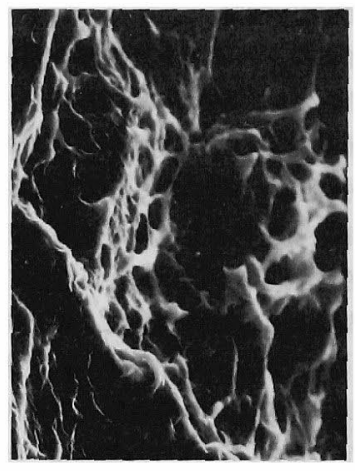

a

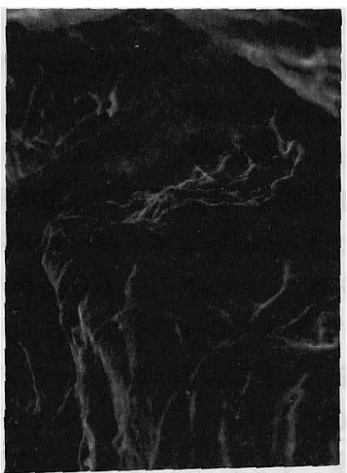

1

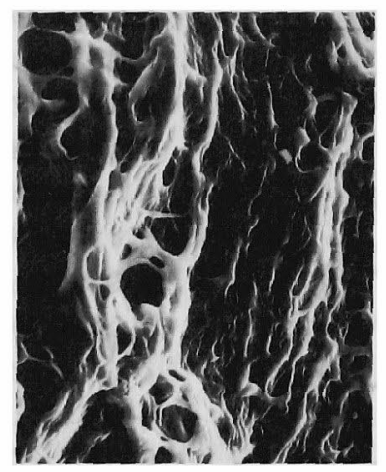

0

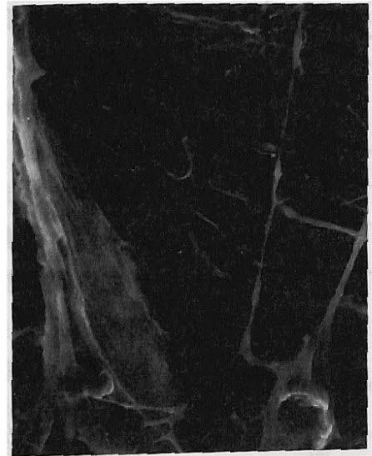

e

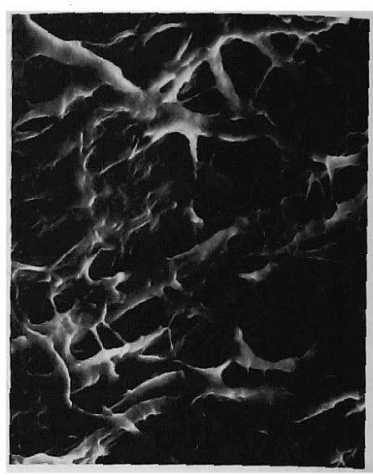

C

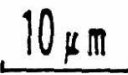

PVA:PAIAM

Q $50: 50$

b $40: 60$

C $30: 70$

d $20: 80$

e $10: 90$

Fig. 6. Scanning electron microphotographs of cross section of dried blend gels.

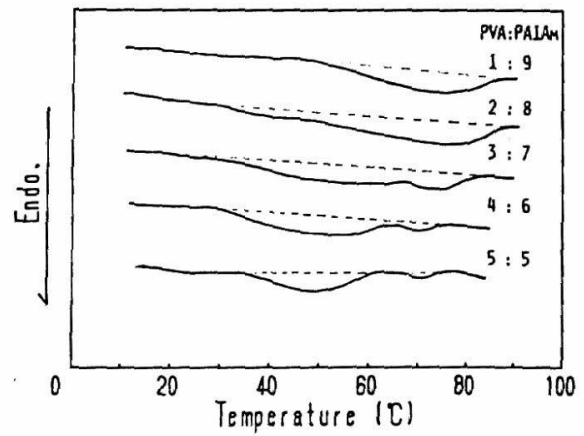

Fig. 7. D. S. C. thermograms of blend gels.

れた蜂の宩状構造とは, 特別な相関があるとは思われな い。そこで高分子の結晶状態や非晶領域での PVA-PA.
IAm 間の相互作用といった分子オーダーでの架橋構造 を解明することが必要と考えられるのでは以下これらの 点を検討する。

\subsection{2 ブレンドゲル中の結晶領域}

図 7 は DSC による各種比ブレンドゲルの溶解挙動で ある。PAlAm をブレンドすると $50^{\circ} \mathrm{C}$ 付近と,これより 高温側 $70^{\circ} \mathrm{C}$ 付近に溶解吸熱ピークが現れる。50 ${ }^{\circ} \mathrm{C}$ 付近 のピークは，PVAのみのゲルでは結晶溶解ピークが55 ${ }^{\circ} \mathrm{C}$ 付近に現われる[6]ことから, PVA 微結晶の溶解に よるものと思われ，このピークはPAIAm 初期混合分率 の増加に伴い大きさが減少する。この隇少の理由は PAIAm 初期混合分率增大により PVA 量が相対的に少な くなることから，PVA 結晶が減少することによるもの と思われる。また, PAlAm 初期混合分率增大に伴い 


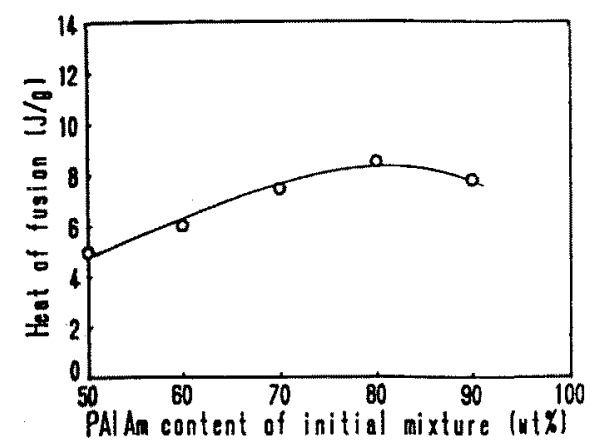

Fig. 8. Dependence of heat of fusion on PAIAm content of initial mixture.

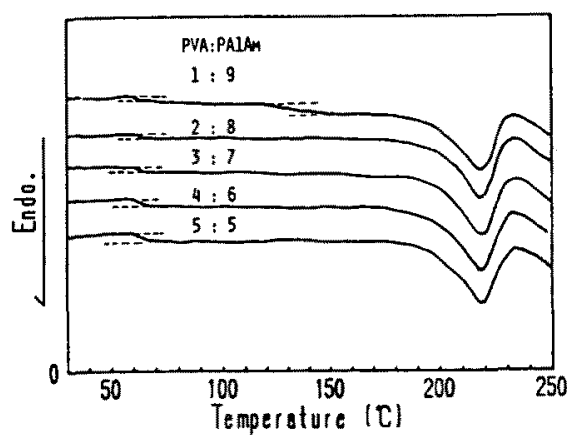

Fig. 9. D. S. C. thermograms of dried blend gels.

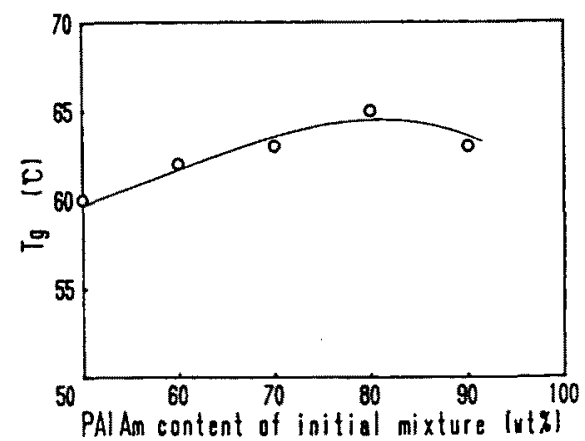

Fig. 10. Dependence of $\mathrm{Tg}$ on PAlAm content of dried blend gels.

PVA 結晶が成少するのであるから先に述べた弾性率の 增大の主要な要因は結晶の成艮による架棉点密度の增加 に起因するものではないと言える。一方，宲温側のピー クは高温側に移動するとともに，全体のピークの大き が增している。ブレンドにより初めて出現する吸热ピー クである事から、この高温側の吸熱ビークはPVAとの 閏にコンプレックスの様な新たな相互作用領域が形成さ れ、これが溶解する事によると考えられる。そしてこの
領琙はPVA綪奛と同様に架橋の役割を果たしていると 予想される。

図 8 はこのような溶解ビーク面積からブレンド試料 1 $\mathrm{g}$ 当りの溶解熱量を求めた結果である。熱量は, PAIAm 初期混合分率が $80 \mathrm{wt} \%$ 付近までは㖃やかに增加L，90 wt\%で急激に減少している。PAIAm 分率が80wt\%付近 までは，相对的な PVA 微結晶部の減少よりもPVAと PAlAmによる相互作用領域の増大の方が大きいため， 総熱量は增加すると考えられる。更に，90 wt\%の PAlAm 分率のものではPVA 微結晶部分の減少に加之, 高温側の相互作用領域の熱量も減少するた如，総熱量 のかなり急激な隇少が生じていると考えられる。このこ とは，先に述べたPAIAm 初期混合分率90 wt\%のブレン ドゲルが架橋密度が低いことと対応している。ゲル中の 結晶としてはPVA 結晶のみが存在すると予想されるこ とから，この相互作用領域㨫晶領域に存在るる事にな る。そこで以下において非晶領域の構造について検討す る。

\subsection{3 ブレンドゲル中の非晶領域}

図 9 は、凍結乾燥試料のDSCの結果である。バース ラインの吸熱側へのシフトとして現れる Tgは, PAIAm 分率 $90 \mathrm{wt} \% の 2 に 64^{\circ} \mathrm{C} と 110^{\circ} \mathrm{C}$ 付近に二つ見られ，前 者はPVAの，後者はPAIAmの Tgであり，その他のブ レンド物ではPVAの Tgのみが出現している。このこ とより，非晶領域に扔いてはPAIAm 分率80 wt\%までの フレンドハイドロゲルは均一混合采で, 主にPVAが非 晶鎖として存在していることを意味しており，一方， PAIAm 分慗90wt\%では不均一涺合系であると言える。 このことは3.1節で記したように巨視的知見とも一致す る。

図10は，PVAの Tgの PAIAm 分率依存性を示したも のである。PAlAm 分率增大に伴い80 wt％までは Tg は、高温側へ移動し, PVA 非晶鎖の動きが制限されて いることを意味している。非晶鎖の連動の制限は，上述 してきたPVAとPAIAmとの間のコンプレックスの形 成が確かに存在し，その影篰が見られることを意味して いる。

過去の商分子閒のコンブレックスの形成は、溶液濃度 5 wt\%以下において起る事が知られているが[17，18]。 本研究のような20 wt\%を超えるような濃厚ブレンド溶 液においても容易にコンプレッタスを形成する理由は， 加压による溶解温度の上昇が分子運動を高め，相兵搪散 と高分子間の接触頻度を增すことによると考えられる。

\section{4 ブレンドゲル中の水の状愳}

得られたダルの水奇率は $80 \%$ 越元ており，水の状態 を検討する必要がある思われる。图11はスピン格子楥 


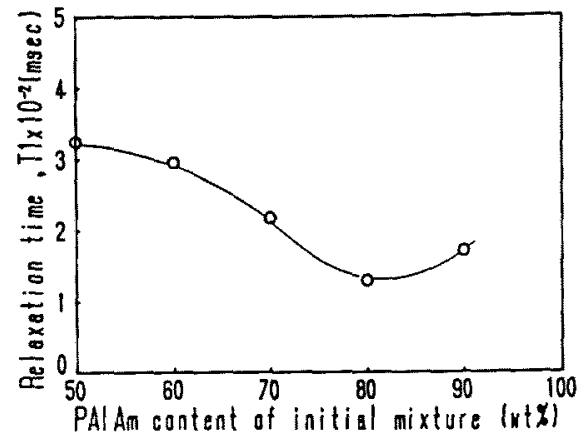

Fig. 11. Dependence of relaxation time on PAIAm content of blend gels.

和時間 $T_{1}$ の PAIAm 初期混合分率依存性を示したもので ある。PAlAm 初期混合分率增加に従い緩和時間 $T_{1}$ は低 下し, 一方 PAIAm 初期混合分率90 wt\%で上帠する。純 水の $\mathrm{T}_{1}$ は2 $20^{\circ} \mathrm{C}$ で約 $2000 \mathrm{msec}$ 程度〔19〕で各ブレンド試 料ともそれより低い值を示す。 $T_{1}$ が小さい程水の分子 連動は不活発になることを考えれば，これらのことは， ブレンドハイドロゲル中の水の動きは制限が大きく，運 動性が低下することを意味している。そしてこの水は 3-2で明らかにしたように，ブレンドにより架橋密度が 増していることから，水は㹨い網目中に閣じこめられる と運動性が低下すると考えられる。尚, ゲル中の高分子 濃度は図 2 で示したようにブレンドにより僅かに濃くな るだけであり，T低下の原因は高分子濃度の增大に よるものではないことを意味している。

\section{4. 結 論}

PVAとカチオン性离分子の PAlAmとの加圧，加熱に より得なブレンドハイドロダルはPAIAm 初期混合分率 が90wt\%以下ではPVAとア二オン性高分子，および PVA と中性高分子の加圧，加熱により得たブレンド八 イドロゲルの構造と類似し 1) 反復凍結解凍法で得られ るPVAハイドロゲルよりも、弾性率は高く、 又弾性率 はPAIAm 分率增加にともない増大する事，2）ゲル中 では $\mu \mathrm{m}$ オーダーの三次元的な蜂の巣状構造が形成され

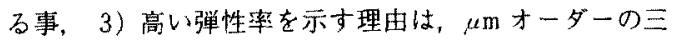
次元的な蜂の米状構造中にPVA 微結晶の形成の他に PVAとPAIAmとにより相互作用により形成されたコン
ブレックスが架桤点としての役割を果たす事による事を 明らかにした。

一方，PAlAm 初期混合分率が90 wt\%ではゲル中で相 分離が起り不均一構造を取ることを明らかにしている。

\section{文葫}

1. 南部昌生, 特部公報, 82-130543（1982）

2, 䒺丞㷊，車 源目，筏義人，高分子論文集， 46, 673 (1989)

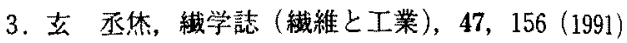

4. M. Watase and K. Nishinari, Polymer, 9, 1254 (1983)

5. M. Nagura, M. Nagura, and H. Ishikawa, Polymer Commun., 25, 313 (1984)

6. M. Nagura, T. Hamano, and H. Ishikawa, Polymer, 30, 762 (1989)

7. 草野智弘, 佐藤 泗, 小見山二郎, 繊維学会シンポ ジウム予稿集, 1990, C-122

8. 比嘉 无, 谷岡明彦, 宮坂敬象, 䌙維学会シンポシ ウム予稿集, $1990, \mathrm{C}-145$

9. 鉿木 誠，高分子論文集，46，603（1989）

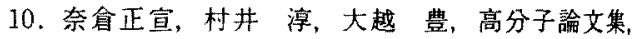
48, 775 (1991)

11. 奈倉正宣、高原和明, 賀川弘海, 西村 弘、石川 博，公開特許公報，平3-161046（1991）

12. 賀川弘海, 大越 豊, 不川 博, 奈目正宣, 第27回 高分子と水に関する討論会講演要旨集, p. 5 (1989)

13，奈會正宣，西村 弘，大越 豊，高分子論文集， 48, $519(1991)$

14. M. Nagura and A. Eisenberg, Polymer, 32, 2205 (1991)

15. P. J. Flory, "Principles in Polymer Chemistry", Cornell Univ. Press. Ithaca, New York (1953)

16. 南部昌生, 高分子加工; 32, 19 (1983)

17. E. A. Bekturov and L. A. Bimendina, Adv. Polym Sci., 41, $100(1981)$

18. 土田英俊，「离分子間コンプレックス」，「機能性意 分子」，8章（高分子学会絀），共立出版（1974）

19. D. E. Woessner. B. S. Jr. Snowden, and Y. C. J. Chin Colloid Interface Sci., 34, 283 (1970) 